\title{
ANALISIS POLITIK ALIH KEWENANGAN PENGELOLAAN GURU SMA/SMK DARI PEMERINTAH KABUPATEN/KOTA KEPADA PEMERINTAH PROVINSI
}

\author{
Nunik Retno Herawati \\ Departemen Ilmu Politik dan Pemerintahan, Fakultas Ilmu Sosial \& Ilmu Politik, \\ Universitas Diponegoro \\ E-mail: nunikretno92@gmail.com
}

\begin{abstract}
Under Law 23 of 2014 on Regional Government, there is a change in the distribution of functions in the management of education. High education previously managed by district / municipality governments turned to the provincial government. This article aims to analyze teachers management before and After the transition of the high education authority of the Regency / City government to the Provincial Government of Central Java using political perspective. Decentralization system has basically opened wide opportunity for each region to play a bigger role, including in the management of teachers in the District / City. Domination of the Head of Region is very visible in the process of recruitment, selection, payroll, career development, placement, mutation and Evaluation Performance Teacher District / City. The recentralization of high education authority, especially the management of teachers at the Provincial Government level, is expected to minimize the occurrence of education politicization at the district / municipality level.
\end{abstract}

Keywords: decentralization; transfer authority; teacher management

\begin{abstract}
Abstrak
Di bawah UU No. 23 tahun 2014 tentang Pemerintahan Daerah, ada perubahan dalam distribusi fungsi untuk manajemen pendidikan. Pendidikan tinggi yang sebelumnya dikelola oleh pemerintah Kabupaten / Kota beralih ke Pemerintah Provinsi. Artikel ini bertujuan untuk menganalisis manajemen guru sebelum dan sesudah transisi dari otoritas pendidikan tinggi pemerintah Kabupaten / Kota kepada Pemerintah Provinsi Jawa Tengah dengan menggunakan perspektif politik. Sistem desentralisasi pada dasarnya membuka peluang luas bagi masing-masing daerah untuk memainkan peran yang lebih besar, termasuk dalam pengelolaan Guru di Kabupaten / Kota. Dominasi Kepala Daerah sangat terlihat dalam proses rekrutmen, seleksi, penggajian, pengembangan karir, penempatan, mutasi dan Evaluasi Kinerja Guru Kabupaten / Kota. Kesimpulan yang didapat adalah Resentralisasi otoritas pendidikan tinggi, terutama manajemen guru di tingkat Pemerintah Provinsi, dapat meminimalkan terjadinya politisasi pendidikan di tingkat Kabupaten / Kota.
\end{abstract}

Kata kunci: desentralisasi; alih wewenang; manajemen guru 


\section{PENDAHULUAN}

Perjalanan sejarah otonomi daerah di indonesia sangat menarik untuk di pelajari dan di kaji lebih dalam terutama ketika perubahan dari masa rezim orde baru yang sentralitas ke masa reformasi yang akhirnya melahirkan model desentralisasi yang ditandai dengan dikeluarkannya UU No 32 tahun 2004 tentang Pemerintahan Daerah. Dalam sistem desentralisasi kekuasaan negara akan terbagi antara 'pemerintah pusat' disatu pihak, dan 'pemerintah daerah' di lain pihak. Desentralisasi juga dimaknai bahwa kewenangan Pemerintah didesentralisasikan ke daerah, ini mengandung makna, pemerintah pusat tidak lagi mengurus kepentingan rumah tangga daerah. Kewenangan mengurus, dan mengatur rumah tangga daerah diserahkan kepada masyarakat di daerah (Ardika dan Sahrul, 2011).

Setelah kurang lebih 10 tahun dilaksanakannya UU No. 32 tahun 2004 tentang Pemerintahan Daerah ternyata telah terjadi beberapa permasalahan dalam pemerintahan Indonesia yang semakin kompleks dan dinamis, khususnya permasalahan di pemerintahan daerah berkenaan dengan pelaksanaan desentralisasi dan otonomi daerah. Permasalahan yang paling mudah untuk dilihat berkaitan dengan desentralisasi dan otonomi di daerah otonom adalah munculnya raja-raja kecil di setiap pemerintah daerah. Persepsi seperti itu menyebabkan setiap pemerintah daerah menjadi lebih sulit untuk dikoordinasikan sehingga pembangunan di daerah banyak yang tidak sejalan dengan pembangunan yang ada di pusat ataupun kurangnya loyalitas pemerintah daerah terhadap setiap tugas atau perintah yang diberikan pemerintah pusat kepada pemerintah daerah.

Pada Tanggal 30 September 2014, Presiden Republik Indonesia telah menandatangani Undang-Undang No. 23 Tahun 2014 tentang Pemerintahan Daerah, menggantikan Undang-Undang No. 32 Tahun 2004, yang dianggap sudah tidak sesuai lagi dengan perkembangan keadaan, ketatanegaraan, dan tuntutan penyelenggaraan pemerintahan daerah. Berdasarkan UU 23 tahun 2014 tentang Pemerintahan Daerah, terdapat perubahan pembagian urusan dalam pengelolaan bidang pendidikan antara pemerintah pusat, pemerintah provinsi, dan pemerintah kabupaten/kota. Pendidikan menengah (SMA/SMK) yang sebelumnya dikelola pemerintah kabupaten/kota berdasar UU tersebut kewenangan pengelolaannya beralih ke pemerintah provinsi.

Tujuan dari pengalihan kewenangan ini pada dasarnya agar pemerintah daerah bisa lebih fokus dalam meningkatkan kualitas pendidikan. Pemerintah kabupaten/kota dapat lebih fokus membenahi pendidikan dasar, Pendidikan Anak Usia Dini (PAUD) dan Pendidikan Masyarakat (Dikmas). Pemkab/pemkot diharapkan bisa mengurusi ini secara optimal dan maksimal. Sementara pemerintah provinsi dapat lebih memprioritaskan 
pendidikan menengahnya. Selain itu, pemprov juga diharapkan bisa menuntaskan program yang dicanangkan pemerintah pusat, yakni Wajib Belajar (wajar) 12 Tahun (Rohman, dkk 2010).

Dalam perspektif politik kebijakan alih kewenangan pendidikan menengah ke Pemerintah Propinsi dimaknai untuk bisa meminimalisir politisiasi pendidikan di level pemerintah Kabupaten/Kota yang selama ini kerap terjadi menjelang Pemilukada. Guru sebagai aktor yang terlibat untuk memberikan sumbangan yang optimal bagi pendidikan, namun, dalam praktek sering dijumpai justru menjadi obyek politik untuk meraih dan memelihara kekuasaan atau berbagai keuntungan politik.

Dalam artikel ini yang akan dianalisis adalah Pertama bentuk politisasi pendidikan sebelum munculnya UU No 23 Tahun 2014 tentang Pemerintahan Daerah; Kedua, gambaran pendidikan menengah di Jawa Tengah; Ketiga, Kebijakan alih kewenangan pengelolaan pendidikan menengah dari pemerintah Kabupaten/Kota ke Pemerintah Propinsi (dibaca : resentralisasi) mampu meminimalisir terjadinya politisasi pendidikan dalam pengelolaan guru pendidikan menengah di Propinsi Jawa Tengah. Masih jarang penelitian yang mengupas mengenai perubahan kewenangan pengelolaan SMU/SMK dari Kabupaten kepada Provinsi. Sehingga penelitian ini bisa dikatakan baru.

\section{METODE PENELITIAN}

Artikel ini ditulis dengan menggunakan metode deskriptif analitik dengan pendekatan kualitatif. Penggunaan pendekatan ini disesuaikan dengan tujuan pokok tulisan ini, yaitu mendeskripsikan dan menganalisis mengenai tata kelola guru setelah muncul kebijakan alih kewenangan pendidikan menengah dari pemerintah Kabupaten/Kota kepada Pemerintah Provinsi. Sumber data yang dikumpulkan dalam artikel ini adalah data primer dan data sekunder. Data Primer dilakukan dengan melakukan pengamatan dan wawancara langsung. Wawancara dilakukan kepada Kepala Dinas Pendidikan Provinsi Jawa Tengah dan staf, Kepala Dinas Pendidikan Kabupaten/Kota di Jawa Tengah. Wawancara juga dilakukan kepada guru SMA/SMK di Jawa Tengah serta masyarakat pemerhati di bidang pendidikan. Sementara Data sekunder yang digunakan dalam analisis ini adalah data dari berbagai Dokumen-Dokumen yakni meneliti dokumen-dokumen dalam bentuk buku-buku, literatur-literatur maupun jurnal-jurnal ilmiah yang berkaitan dengan topik yang ditulis dalam artikel ini. 


\section{HASIL DAN PEMBAHASAN}

Batasan mengenai konsep desentralisasi dikemukakan oleh banyak ahli pemerintahan. Perbedaan sudut pandang para ahli mengakibatkan batasan yang pasti mengenai konsep desentralisasi sulit diperoleh. Perserikatan Bangsa-Bangsa sebagaimana dikutip oleh Koswara (2004) memberikan batasan bahwa desentralisasi adalah "decentralization refers to the transfer of authority away from the national capital wheter by deconcentration (i.e. delegation) to field office or by devolution to local authorities or local bodies".

Dari definisi tersebut menjelaskan bahwa terdapat proses penyerahan (transfer) kekuasaan dari pemerintah pusat (the national capital) dengan dua variasi yaitu (1) melalui dekonsentrasi (delegasi) kepada pejabat instansi vertikal di daerah atau (2) melalui devolusi (pengalihan tanggung jawab) kekuasaan pada pemerintahan yang memiliki otoritas pada daerah tertentu atau lembaga-lembaga otonom di daerah.

Definisi lainnya mendefinisikan desentralisasi sebagai proses penyerahan kekuasaan pemerintah berikut fungsi-fungsinya yang dibedakan menjadi (1) dekonsentrasi yaitu kekuasaan dan fungsi pemerintahan diberikan secara administratif kepada instansi vertikal pemerintah pusat yang ada di daerah dan (2) devolusi yaitu kekuasaan dan fungsi pemerintahan diberikan kepada pemerintah lokal yang memiliki kekuasaan pada wilayah tertentu dalam ikatan suatu negara sehingga terwujud daerah otonom (Harris, 2005)

Definisi tentang desentralisasi tidak ada yang tunggal, namun banyak definisi yang dikemukakan oleh para pakar. Namun secara garis besar ada dua definisi tentang desentralisasi, yaitu dari persepektif administrasi dan persepektif politik (Hidayat, 2000). Berdasarkan perspektif administratif, desentralisasi didefinisikan sebagai the transfer of administrative responsibility from central to local governments. Disini desentralisasi sesungguhnya kata lain dari dekosentrasi. Menurut Parson, dekonsentrasi adalah the sharing of power between members of the same ruling group having authority respectively in different areas of the state. Disini tidak ada transfer kewenangan yang nyata, bawahan hanya menjalankan kewenangan atas nama atasannya dan bertanggung jawab kepada atasannya. (Hidayat dan Hoessin, 2000).

Dalam perspektif politik, Smith dalam Lili Romli mengatakan desentralisasi adalah the transfer of power, from top level to lower level,in a territorial hierarchy, which could be one of government within a state,or officers within a large organization.(Romli, 2007: 5) Disini ada devolusi kekuasaan, bukan sekedar delegasi. Dari penjelasan diatas dapat diketahui perbedaan antara dua perspektif ini terletak pada rumusan definisi desentralisasi itu 


\section{Jurnal Ilmu Sosial Vol. 16 | No. 2 | Edisi Juli - Desember 2017 | Hal.72-93}

sendiri. Perspektif desentralisasi politik mendefinsikan desentralisasi sebagai devolusi kekuasaan dari pemerintah pusat kepada pemerintah daerah. Tujuan dari desentralisasi disini adalah mewujudkan demokratisasi ditingkat lokal sebagai persamaan politik, akuntabilitas lokal, dan kepekaaan lokal. Sedangkan persepektif desentralisasi administrasi mendefinisikan desentralisasi sebagai delegasi wewenang administrative, dari pemerintah pusat ke pemerintah daerah. Disini tujuan utama desentralisasi adalah lebih menekankan pada aspek efisiensi penyelenggaraaan pemerintahan daerah dan pembangunan ekonomi di daerah.

Pelaksanaan UU No. 32 tahun 2004 tentang Pemerintahan Daerah ternyata telah menyebabkan beberapa permasalahan dalam pemerintahan Indonesia yang semakin kompleks dan dinamis, khususnya permasalahan di pemerintahan daerah berkenaan dengan pelaksanaan desentralisasi dan otonomi daerah. Permasalahan yang paling mudah untuk dilihat adalah adanya politisasi pendidikan yang semakin menguat saat para calon Bupati/ Walikota menjadikan pendidikan sebagai isu hangat disamping isu sosial ekonomi dan keamanan. Pemilihan kepala daerah tidak akan terlepas dari janji-janji di bidang pendidikan, mulai dari sekolah gratis, beasiswa, hingga perbaikan sekolah. Contoh dari Kebijakan pendidikan gratis terjadi di Kabupaten Rembang yang merupakan kebijakan politis dan populis yang dinisiasi oleh Bupati Rembang Bapak Mohamad Salim. Selain itu kebijakan Pendidikan gratis juga terjadi di Kabupaten Sukoharjo, Kota Semarang serta Kota Tegal.

Politisasi pendidikan juga terjadi dalam pengelolaan guru di daerah. Pelantikan kepala daerah baru biasanya diikuti dengan mutasi besar-besaran baik di lingkungan birokrasi pendidikan maupun di tingkat guru. Politisasi itu bahkan terus terjadi jauh setelah pelaksanaan pilkada, baik dalam tahap rekrutmen, promosi, maupun mutasi guru. Politisasi tidak hanya mengganggu karir, tapi juga sebaran guru. Mereka yang dianggap tidak mendukung Kepala Daerah akan ditempatkan di daerah-daerah terpencil, sebaliknya para tim sukses akan mendapat ganjaran jabatan atau setidaknya dipindahkan ke daerah perkotaan. Ini merupakan bagian kecil dari karut-marut tata kelola guru terkait dengan desentralisasi pendidikan.

Yulianto Kadji Guru Besar Kebijakan Publik Universitas Negeri Gorontalo menjelaskan bahwa sejak UU No. 22 Tahun 1999 sampai UU No. 23 Tahun 2014, memberikan kewenangan sepenuhnya kepada pemerintah kabupaten/kota untuk mengelola sepenuhnya satu diantaranya adalah pembinaan guru pendidikan dasar dan menengah. Bersamaan dengan desentralisasi otonomi daerah, Pemilihan Kepala Daerah/ Wakil Kepala Daerah secara langsung digelar dan inilah dipastikan seluruh elemen dan komunitas rakyat dari berbagai latar belakang profesi yang berbeda, termasuk organisasi dan profesi Guru. 
Ada beberapa cara pelibatan Kepala Sekolah dan Guru dalam politik praktis menjelang Pilkada, antara lain:

\section{Penunjukan Kepala Sekolah sebagai Pembina Kelurahan}

Beberapa Kepala Sekolah di daerah tertentu yang intinya mengatakan bahwa : "Kami Kepala Sekolah ditunjuk sebagai Pembina Kelurahan, dengan alasan bahwa keberadaan Kepala Sekolah di Kelurahan paling tidak akan mempengaruhi secara psikologis warga masyarakat termasuk Guru-guru yang di Kelurahan tersebut, dan memastikan pilihan mereka pada figur tertentu yang perintahkan oleh atasan bahkan Kepala Daerah dalam forum-forum resmi.

2. Penunjukan Pengawas Sekolah sebagai penanggungjawab kecamatan

3. Pelibatan Guru dalam beberapa kegiatan politik praktis

Guru dipandang sebagai komunitas yang paling mudah untuk di mobilisir pada kegiatan yang menguntungkan pihak atau calon tertentu. Terkadang ada kegiatan yang dilaksanakan tidak seperti biasa, bahkan tidak pernah ada selama ini, tapi tiba-tiba muncul berbagai kegiatan menjelang pelaksanaan Pilkada, dan otomatis melibatkan Guru yang begitu mudahnya untuk di mobilisir. Beberapa Guru yang sempat diwawancarai mengatakan bahwa : "kami para Guru tidak bisa berbuat apa-apa kecuali ikut saja perintah atasan, berhubungan dengan siapa yang akan dipilih dalam Pilkada”.

Hasil temuan PGRI memunjukkan bahwa modus dalam mempolitisasi Guru pada Pilkada, antara lain :

1. Memperbanyakan Frekwensi pertemuan Guru dengan Kepala Daerah (Incumbent);

2. Hampir di setiap acara para Guru dijadikan sebagai momentum sosialisasi incumbent atau yang didukung oleh organisasi Guru (PGRI);

3. Menggunakan dana BOS untuk pembuatan spanduk, pamplet-pamplet untuk sosialisasi

4. Klaim program pendidikan sebagai program utama Incumbent;

5. Mobilisasi dukungan melalui Kepala Dinas Pendidikan;

6. Janji promosi jabatan kepada para Guru.

7. Janji peningkatan kesejahteraan kepada para Guru.

Janji Calon Bupati Pekalongan Tahun 2015 dalam visi dan misnya menyatakan Menyediakan pendidikan gratis 12 tahun dan meningkatkan mutu pendidikan yang memiliki daya saing. Selain itu menyediakan jaminan dan pelayanan pendidikan dasar gratis selama 12 tahun meliputi tingkat SD, SLTP, dan SLTA serta memberikan beasiswa bagi siswa berprestasi dan berpotensi. 
Bupati Boyolali Drs. H Seno Samodro juga melakukan mutasi pegawai negeri sipil (PNS) secara besar-besaran setelah enam bulan kembali menjabat sebagai Bupati Boyolali periode 2016-2021. Pegawai yang dimutasi kebanyakan adalah pejabat eselon III dan IV, termasuk kepala sekolah di Kabupaten Boyolali. Menurut informan yang diwawancara mengatakan "meski Baperjakat menjalankan perannya untuk memberikan pertimbangan mutasi kepada BKD dan Bupati, namun pertimbangan dan keputusan berada di tangan Bupati sangat berpengaruh karena bersifat Final".

Paling tidak ada tiga alasan mengapa Guru lebih mudah untuk dilibatkan langsung dalam Pilkada : Pertama, guru berperan dalam bidang yang strategis, yakni pendidikan yang bersentuhan langsung dengan public. Kedua, alam kekuasaan otonomi daerah, guru lebih mudah untuk dipengaruhi melalui sistem birokrasi dengan menggunakan tangan Kepala Dinas Pendidikan. Ketiga, komunitas guru masih dipandang sebagai tokoh masyarakat yang begitu mudah melakukan pendekatan kepada masyarakat untuk dipengaruhinya memilih pasangan calon tertentu dalam Pilkada. Jika ternyata ada Kepala Sekolah atau Guru yang membangkang, maka yang terjadi antara lain:

Kepala Dinas dan Kepala Sekolah pasti non job, Guru dimutasi ke daerah terpencil, Guru dimutasi menjadi anggota Satpol PP, atau ke unit kerja yang tidak sesuai kompetensi Guru. Berbagai pelanggaran dan modus pelibatan Guru dalam Politik Pilkada yang selama ini terjadi jarang mendapat perhatian serius, sehingga sulit untuk di proses dalam kerangka penegakkan hukum Pilkada. Dan kondisi inilah yang menguntungkan calon Kepala Daerah incumbent atau keluarga dan kroninya menjadi calon kepala daerah atau wakil kepala daerah, karena adanya kemudahan dan fasilitas yang memungkinkan calon bersangkutan menggunakan pengaruhnya untuk mengganggu netralitas dan independensi guru.

Koordinator ICW Ade Irawan menjelaskan "hampir semua masalah pokok terkait dengan guru yang muncul, trenyata dari bersumber masalah kewenangan pengelolaan guru. Hasil riset menemukan adanya kecenderungan pemerintah daerah yang hanya memilih kebijakan-kebijakan yang mengentungkan secara politik seperti pengangkatan, distribusi, hingga mutasi"”.

Hasil kajian Indonesia Corruption Watch tentang pengelolaan guru memperlihatkan beberapa masalah terkait dengan rekrutmen dan pendidikan calon guru, status dan kesejahteraan, kepangkatan dan pengembangan karir, dan ketimpangan persebaran guru, disebabkan antara lain oleh belum jelasnya pembagian tugas antara pemerintah pusat dengan pemerintah daerah (www.transformasipendidikan.org) 
Undang-undang 14/2015 tentang Guru dan Dosen maupun Peraturan Pemerintah $74 / 2008$ tentang guru belum mengatur secara jelas porsi pembagian tugas secara teknis antara pemerintah pusat dan pemerintah daerah. Ketidakjelasan tersebut membuat pemerintah daerah cenderung memilih-milih kebijakan yang cenderung menguntungkan secara politis seperti distribusi dan mutasi guru, sedangkan peningkatan kapasitas dan kesejahteraan umumnya mereka abaikan. Permasalahan Guru di Daerah bisa dilihat pada tabel 1 .

Tabel 1. Masalah Guru di Daerah

\begin{tabular}{|c|c|c|}
\hline NO & KEBIJAKAN & KENYATAAN \\
\hline 1 & Pengangkatan & $\begin{array}{l}\text { 1. Usulan formasi daerah dianggap kurang diakomodir sehingga } \\
\text { daerah melakukan rekrutmen guru sendiri. Umumnya tanpa } \\
\text { didasari standar yang jelas } \\
\text { 2. Rekrutmen oleh pemerintah daerah sering didasarkan pada per- } \\
\text { timbangan politis (mengakomodir tim sukses/pendukung) } \\
\text { 3. Sekolah bisa melakukan rekrutmen yang disesuaikan dengan } \\
\text { standar kualifikasi masing-masing sekolah } \\
\text { 4. Rekrutmen oleh sekolah umumnya tidak disertai perjanjian } \\
\text { kerja }\end{array}$ \\
\hline 2 & Kompetensi & $\begin{array}{l}\text { 1. Guru-guru yang diangkat sekolah (diselenggarakan masyarakat } \\
\text { atau negara) tidak didasarkan pada pertimbangan kompetensi, } \\
\text { tapi kekerabatan } \\
\text { 2. Pemerintah daerah dan sekolah umumnya tidak memiliki pro- } \\
\text { gram/anggaran untuk meningkatkan kompetensi guru }\end{array}$ \\
\hline
\end{tabular}

$\begin{array}{ll}3 \mathrm{Hak} / & \text { 1. Pemerintah daerah dan sekolah umumnya mengandalkan } \\ \text { Kesejahteraan } & \text { pemerintah pusat }\end{array}$
4 Penempatan 1. Politisasi mutasi guru oleh pemerintah daerah terutama men- dan jelang dan setelah pilkada
pemindahan 2. Bagi guru honorer di institusi pendidikan yang diselenggarakan masyarakat biasanya dilakukan karena faktor suka atau tidak suka




\begin{tabular}{|c|c|c|}
\hline NO & KEBIJAKAN & KENYATAAN \\
\hline 5 & $\begin{array}{l}\text { Pengembangan } \\
\text { dan peningkatan } \\
\text { kualitas akademik, } \\
\text { kompetensi, dan } \\
\text { keprofesionalan }\end{array}$ & $\begin{array}{l}\text { 1. Pengembangan/peningkatan kualitas mengandalkan pro- } \\
\text { gram dari pemerintah pusat. Alasan utamanya berkaitan } \\
\text { dengan anggaran, namun banyak pula yang tidak paham } \\
\text { terkait peningkatan kualitas guru. } \\
\text { 2. Pelatihan/pengembangan kapasitas yang bisa disediakan } \\
\text { pemerintah pusat terbatas } \\
\text { 3. Sekolah biasanya akan mengikutsertakan guru PNS sebagai } \\
\text { peserta, sedangkan guru honor tidak diprioritaskan }\end{array}$ \\
\hline 6 & Pembinaan & $\begin{array}{l}\text { 1. Politisasi pembinaan oleh pemerintah daerah/dinas untuk } \\
\text { kepentingan pemilihan maupun membungkam guru-guru } \\
\text { kritis. } \\
\text { 2. Pendidikan yang diselenggarakan oleh institusi pendidikan } \\
\text { yang diselenggarakan masyarakat umumnya tidak memiliki } \\
\text { program pembinaan untuk guru }\end{array}$ \\
\hline 7 & Pemberhentian & $\begin{array}{l}\text { 1. Guru di institusi pendidikan yang diselenggarakan } \\
\text { masyarakat umumnya tidak memiliki perjanjian kerja se- } \\
\text { hingga bisa dengan mudah diberhentikan oleh pemilik }\end{array}$ \\
\hline
\end{tabular}

Sumber : http://transformasipendidikan.org

Undang Undang Nomor 23 Tahun 2014 tentang Pemerintahan Daerah telah menempatkan kewenangan Pemerintah Provinsi sebagai penyelenggara dan pengelola pendidikan menengah dan pendidikan khusus. Ada beberapa alasan mengapa kewenangan Pendidikan Menengah dialihkan kepada pemerintah Provinsi yaitu :

1. Untuk mengurangi disparitas pembangunan pendidikan menengah di Kabupaten/Kota dan menciptakan mutu yang relatif sama di Kabupaten/Kota dalam wilayah Provinsi Jawa Tengah;

2. Untuk menghindari politik lokal yang berimbas pada relatif lambatnya proses pembangunan pendidikan menengah di daerah;

3. Dalam rangka mendukung pencapaian salah satu visi dan misi dalam nawacita pemerintah yang terkait dengan pendidikan, yakni meningkatkan kualitas hidup manusia Indonesia melalui program Indonesia Pintar dalam Kebijakan Wajib Belajar 12 Tahun bebas pungutan. 
Dalam Pasal 404 Undang-Undang Nomor 23 Tahun 2014 antara lain dinyatakan bahwa serah terima personil, pendanaan, sarana dan prasarana, serta dokumen (P3D) sebagai akibat pembagian urusan pemerintahan antara Pemerintah Pusat, Daerah Provinsi dan Daerah Kabupaten/Kota yang diatur berdasarkan Undang-Undang ini dilakukan paling lama 2 (dua) tahun terhitung sejak Undang-Undang ini diundangkan. Sebagai tindak lanjut dari keluarnya UU No. 23 Tahun 2014 tentang Pemerintahan, Pemerintah telah mengeluarkan juknis antara lain :

1. Surat Edaran Mendagri nomor 120/253/sj tanggal 16 Januari 2015 tentang Penyelenggaraan Urusan Pemerintahan Setelah ditetapkannya UU No. 23 Tahun 2014 tentang Pemerintahan Daerah.

2. Surat Edaran Mendagri nomor 120/5935/SJ tanggal 16 Oktober 2015 tentang Percepatan Pelaksanaan Pengaliahan Urusan berdasarkan UU No. 23 Tahun 2014 tentang Pemerintahan Daerah ; dan Lampirannya

3. Surat Edaran Dirjen Pendidikan Dasar dan Menengah Nomor 3603/D/DM/2015 tanggal 24 Agustus 2015 tentang Pengelolaan Pendidikan Menengah setelah ditetapkan UU No.

23 Tahun 2014 tentang Pemerintahan Daerah

Di Provinsi Jawa Tengah saat ini telah tercatat sebanyak 2.284 Satuan Pendidikan Menengah, yaitu SMA dan SMK, dengan rincian sebagai berikut : 855 SMA, terdiri atas 363 SMA Negeri dan 492 SMA Swasta; dan terdapat 1.429 SMK, terdiri atas 219 SMK Negeri dan 1.210 SMK Swasta. Persebaran Sekolah Menengah atau ketersediaannya di wilayah Kecamatan se Jawa Tengah Tahun 2014 bisa dilihat pada tabel 2.

Tabel 2. Persebaran Sekolah Menengah di Jawa Tengah

\begin{tabular}{lllllll}
\hline No & $\begin{array}{c}\text { Kabupaten / } \\
\text { Kota }\end{array}$ & $\begin{array}{c}\text { Jml } \\
\text { Kec }\end{array}$ & $\begin{array}{c}\text { Jml } \\
\text { SMP }\end{array}$ & $\begin{array}{c}\text { Jml } \\
\text { SM }\end{array}$ & $\begin{array}{c}\text { Ratio } \\
\text { SM : } \\
\text { SMP }\end{array}$ & $\begin{array}{c}\text { Belum Memiliki Sekolah } \\
\text { Menengah }\end{array}$ \\
\hline 1 & Kab Semarang & 19 & 140 & 63 & 0,45 & Kec Tuntang \\
\hline 2 & Kab Kendal & 20 & 151 & 78 & 0,52 & Kec. Plantungan dan Ringinarum \\
\hline 3 & Kab Demak & 14 & 213 & 90 & 0,42 & \\
\hline 4 & Kab Grobogan & 19 & 234 & 74 & 0,32 & \\
\hline 5 & Kab Pekalongan & 19 & 127 & 46 & 0,36 & Kec. Wonokerto \\
\hline 6 & Kab Batang & 15 & 108 & 38 & 0,35 & Kec Tulis \\
\hline 7 & Kab Tegal & 18 & 181 & 88 & 0,49 & \\
\hline 8 & Kab Brebes & 17 & 240 & 99 & 0,41 & \\
\hline 9 & Kab Pati & 21 & 225 & 64 & 0,28 & \\
\hline
\end{tabular}


Jurnal Ilmu Sosial Vol. 16 | No. 2 |Edisi Juli - Desember 2017 | Hal.72-93

Tabel 2. Persebaran Sekolah Menengah di Jawa Tengah

\begin{tabular}{|c|c|c|c|c|c|c|}
\hline No & Kabupaten /Kota & $\begin{array}{l}\text { Jml } \\
\text { Kec }\end{array}$ & $\begin{array}{l}\text { Jml } \\
\text { SMP }\end{array}$ & $\begin{array}{l}\mathbf{J m l} \\
\text { SM }\end{array}$ & $\begin{array}{l}\text { Ratio } \\
\text { SM : } \\
\text { SMP }\end{array}$ & $\begin{array}{c}\text { Belum Memiliki Sekolah } \\
\text { Menengah }\end{array}$ \\
\hline 10 & Kab Kudus & 9 & 115 & 43 & 0,37 & \\
\hline 11 & Kab Pemalang & 14 & 164 & 67 & 0,41 & Kec. Pulosari \\
\hline 12 & Kab Jepara & 16 & 190 & 64 & 0,34 & \\
\hline 13 & Kab Rembang & 14 & 99 & 39 & 0,39 & Kec Pancur \\
\hline 14 & Kab Blora & 16 & 138 & 75 & 0,54 & Kec Bogorejo \\
\hline 15 & Kab Banyumas & 27 & 210 & 107 & 0,51 & Kec. Lumbir \\
\hline 16 & Kab Cilacap & 24 & 276 & 105 & 0,38 & \\
\hline 17 & Kab Purbalingga & 18 & 129 & 48 & 0,37 & Kec Pengadegan \\
\hline 18 & Kab Banjarnegara & 20 & 142 & 34 & 0,24 & $\begin{array}{l}\text { Kec Pagentan, Pan-danarum dan } \\
\text { Susukan }\end{array}$ \\
\hline 19 & Kab Magelang & 21 & 217 & 79 & 0,36 & \\
\hline 20 & Kab Temanggung & 20 & 117 & 37 & 0,32 & $\begin{array}{l}\text { Kec Bejen, Tlogo-mulyo, Tretep } \\
\text { dan Wonoboyo }\end{array}$ \\
\hline 21 & Kab Wonosobo & 15 & 137 & 42 & 0,31 & Kec Kalikajar \\
\hline 22 & Kab Purworejo & 16 & 114 & 66 & 0,58 & \\
\hline 23 & Kab Kebumen & 26 & 204 & 93 & 0,46 & Kec Alian dan Pon-cowarno \\
\hline 24 & Kab Klaten & 26 & 135 & 88 & 0,65 & Kec Kemalang \\
\hline 25 & Kab Boyolali & 19 & 138 & 78 & 0,57 & \\
\hline 26 & Kab Sragen & 20 & 118 & 74 & 0,63 & Kec Sidoharjo \\
\hline 27 & Kab Sukoharjo & 12 & 84 & 56 & 0,67 & \\
\hline 28 & Kab Karanganyar & 17 & 101 & 49 & 0,49 & $\begin{array}{l}\text { Kec Jatiyoso, Ngar-goyoso dan } \\
\text { Tawangmangu }\end{array}$ \\
\hline 29 & Kab Wonogiri & 25 & 145 & 63 & 0,43 & $\begin{array}{l}\text { Kec Batuwarno, Karangtengah, } \\
\text { Ngadirojo dan Puhpelem }\end{array}$ \\
\hline 30 & Kota Semarang & 16 & 216 & 182 & 0,84 & \\
\hline 31 & Kota Salatiga & 4 & 28 & 27 & 0,96 & \\
\hline 32 & Kota Pekalongan & 4 & 35 & 22 & 0,63 & \\
\hline 33 & Kota Tegal & 4 & 36 & 32 & 0,89 & \\
\hline 34 & Kota Magelang & 3 & 23 & 31 & 1,35 & \\
\hline \multirow[t]{2}{*}{35} & Kota Surakarta & 5 & 80 & 85 & 1,06 & \\
\hline & JUMLAH & 573 & 5.010 & 2.287 & 0,46 & 29 Kec \\
\hline
\end{tabular}

Sumber : Data Profil Pendidikan Menengah, Kemdikbud 2013/2014 
Wilayah kecamatan yang belum memiliki Sekolah Menengah merupakan wilayah prioritas untuk program pendirian Sekolah Menengah baru (SMA/SMK). Wilayah dengan ratio SM:SMP di bawah 50\% merupakan prioritas untuk menambah akses layanan pendidikan menengah, melalui pendirian satuan pendidikan menengah baru. Semua lulusan Sekolah Menengah Pertama atau sederajat, diharapkan mampu tertampung di Satuan Pendidikan Menengah atau Sekolah Menengah (SMA/SMK). Hal ini selaras dengan Peraturan Menteri Pendidikan dan Kebudayaan RI Nomor 80 Tahun 2013 tentang Pendidikan Menengah Universal, Pasal 4 Ayat 5 yang menyatakan bahwa:

"Pemerintah dan pemerintah daerah sesuai kewenangannya menjamin tersedianya satu satuan pendidikan menengah di setiap wilayah kecamatan di Indonesia. “

Di masa depan, Pemerintah Provinsi memiliki tanggungjawab langsung atas kewenangan perijinan yang merupakan pemberian ijin kepada masyarakat atau pihak lain (pemerintahan Kabupaten/Kota/Pusat) yang akan berkontribusi terhadap penyediaan akses pendidikan menengah di daerah. Namun demikian, upaya perluasan akses atau pemerataan pendidikan menengah tidak boleh mengabaikan standar pelayaan minimal pendidikan yang menjadi salah satu prasyarat penting untuk penyediaan akses layanan pendidikan yang bertanggungjawab. Masyarakat atau anak-anak usia pendidikan menengah harus mendapatkan perlindungan melalui kebijakan perizinan pendirian Sekolah Menengah baru ini. Lembaga atau yayasan penyelenggara pendidikan menengah harus mampu memenuhi Standar Pelayanan Minimal (SPM) bidang Pendidikan Menengah, sehingga diharapkan Satuan Pendidikan Menengah atau sekolah dimaksud mampu menyelenggarakan proses pendidikan menengah secara memadai dan bermutu, dan tidak berorientasi pada profit. Dari sebanyak 2.284 SMA dan SMK di Jawa Tengah mampu menampung sebanyak 980.083 siswa, dengan rincian bisa dilihat pada tabel 3 .

Tabel 3. Jumlah Siswa SMA dan SMK di Jawa Tengah Tahun Pelajaran 2014/2015

\begin{tabular}{lrrr}
\hline \multicolumn{1}{c}{ Siswa } & \multicolumn{1}{c}{ Negeri } & \multicolumn{1}{c}{ Swasta } & \multicolumn{1}{c}{ Jumlah } \\
\hline SMA & 267.476 & 90.715 & 358.191 \\
\hline SMK & 183.093 & 438.799 & 652.654 \\
\hline$\sum$ & $\mathbf{4 4 0 . 5 6 9}$ & $\mathbf{5 2 9 . 5 1 4}$ & $\mathbf{9 8 0 . 0 8 3}$ \\
\hline
\end{tabular}

Sumber : Dapodikmen 2014/2015 
Dari data siswa SMA dan SMK tahun pelajaran 2014/2015 di Jawa Tengah yang keseluruhannya berjumlah 980.083 siswa, dapat disimpulkan bahwa rata-rata ratio SMA Negeri dan Siswa adalah $1: 736$, sedangkan untuk SMA Swasta adalah 1:185. Rata-rata ratio SMK Negeri dan Siswa adalah 1 : 836, sedangkan untuk SMK Swasta adalah 1 : 363. Hal ini menunjukkan bahwa animo penduduk usia sekolah menengah (16-18 tahun) untuk melanjutkan pendidikan ke SMK (63\%) lebih besar dibandingkan dengan animo untuk melanjutkan pendidikan di SMA (37\%).

Tabel 4. Jumlah Guru dan Tenaga Kependidikan (GTK) SMA dan SMK Di Jawa Tengah Tahun Pelajaran 2014/2015

\begin{tabular}{lccc}
\hline Sekolah & \multicolumn{3}{c}{ Status Guru } \\
\cline { 2 - 4 } & PNS & Non PNS & Jumlah \\
\hline SMA & 12.419 & 10.204 & 22.623 \\
& $(54,90 \%)$ & $(45,10 \%)$ & \\
\hline SMK & 9.260 & 26.607 & 35.867 \\
& $(25,82 \%)$ & $(74,18 \%)$ & 58.490 \\
\hline$\sum$ & 21.679 & 36.811 & \\
\hline
\end{tabular}

Sumber : Dapodikmen 2014/2015

Dari tabel 4 di atas dapat dilihat bahwa jumlah keseluruhan Pendidik dan Tenaga Kependidikan di Jawa Tengah adalah 58.490 orang yang terdiri atas 21.679 orang yang berstatus sebagai Pegawai Negeri Sipli (PNS) dan sebanyak 36.811 orang berstatus sebagai Non-Pegawai Negeri Sipil (Non-PNS). Dari sebanyak 21.679 orang guru dan tenaga kependidikan SMA/SMK yang berstatus PNS, proporsi berdasarkan golongan di 35 Kabupaten/Kota ada pada tabel 5. 
Jurnal Ilmu Sosial Vol. 16 | No. 2 |Edisi Juli - Desember 2017 | Hal.72-93

Tabel 5. Jumlah Guru dan Tenaga Kependidikan (GTK) PNS di SMA/SMK berdasarkan Golongan, Tahun Pelajaran 2014/2015

\begin{tabular}{|c|c|c|c|c|c|c|c|c|c|c|c|c|}
\hline \multirow{3}{*}{$\begin{array}{l}\mathbf{N} \\
\mathbf{O}\end{array}$} & \multirow{3}{*}{ КАВ/KOTA } & \multicolumn{5}{|c|}{ SMA } & \multicolumn{5}{|c|}{ SMK } & \multirow{3}{*}{ Total } \\
\hline & & \multicolumn{4}{|c|}{ golongan } & \multirow{2}{*}{$\underset{\text { h }}{\text { Jumla }}$} & \multicolumn{4}{|c|}{ golongan } & \multirow[t]{2}{*}{ Jumlah } & \\
\hline & & IV & III & II & $\mathbf{I}$ & & IV & III & II & $\mathbf{I}$ & & \\
\hline 1 & Kab.Banjarnegara & 75 & 178 & 35 & 1 & 289 & 38 & 95 & 4 & & 137 & 426 \\
\hline 2 & Kab.Banyumas & 193 & 254 & 124 & 14 & 585 & 199 & 250 & 29 & 6 & 484 & 1.069 \\
\hline 3 & Kab. Batang & 71 & 102 & 19 & 1 & 193 & 32 & 61 & 13 & 3 & 109 & $\overline{302}$ \\
\hline 4 & Kab. Blora & 69 & 132 & 37 & 2 & 240 & 101 & 62 & 1 & 0 & 164 & $\overline{404}$ \\
\hline 5 & Kab. Boyolali & 175 & 241 & 60 & 6 & 482 & 91 & 138 & 9 & 4 & 242 & $\overline{724}$ \\
\hline 6 & Kab. Brebes & 189 & 200 & 48 & 7 & 444 & 46 & 85 & 12 & 1 & 144 & 588 \\
\hline 7 & Kab. Cilacap & 235 & 241 & 25 & 1 & 502 & 115 & 203 & 6 & 2 & 326 & $\overline{828}$ \\
\hline 8 & Kab. Demak & 111 & 166 & 11 & 2 & 290 & 27 & 52 & 7 & 0 & 86 & 376 \\
\hline 9 & Kab.Grobogan & 149 & 174 & 13 & 2 & 338 & 53 & 82 & 2 & 0 & 137 & 475 \\
\hline 10 & Kab.Jepara & 122 & 200 & 54 & 10 & 386 & 48 & 119 & 7 & 0 & 174 & 560 \\
\hline 11 & Kab.Karanganyar & 164 & 163 & 62 & 10 & 399 & 90 & 206 & 31 & 6 & 333 & 732 \\
\hline 12 & Kab. Kebumen & 123 & 175 & 75 & 8 & 381 & 137 & 207 & 35 & 7 & 386 & 767 \\
\hline 13 & Kab. Kendal & 103 & 167 & 27 & 3 & 300 & 46 & 142 & 2 & 1 & 191 & $\overline{491}$ \\
\hline 14 & Kab. Klaten & 395 & 172 & 56 & 0 & 623 & 250 & 364 & 27 & 1 & 642 & 1.265 \\
\hline 15 & Kab. Kudus & 140 & 129 & 31 & 4 & 304 & 78 & 114 & 9 & 4 & 205 & 509 \\
\hline 16 & Kab.Magelang & 192 & 103 & 16 & 3 & 314 & 70 & 100 & 5 & 1 & 176 & 490 \\
\hline 17 & Kab.Pati & 139 & 118 & 21 & 4 & 282 & 125 & 45 & 9 & 3 & 182 & 464 \\
\hline 18 & Kab.Pekalongan & 25 & 116 & 48 & 5 & 194 & 42 & 92 & 8 & 0 & 142 & 336 \\
\hline 19 & Kab.Pemalang & 122 & 155 & 42 & 9 & 328 & 31 & 193 & 6 & 3 & 233 & 561 \\
\hline 20 & Kab.Purbalingga & 80 & 107 & 29 & 7 & 223 & 71 & 117 & 6 & 3 & 197 & 420 \\
\hline 21 & Kab.Purworejo & 244 & 152 & 25 & 3 & 424 & 120 & 114 & 11 & 0 & 245 & 669 \\
\hline 22 & Kab.Rembang & 72 & 212 & 45 & 6 & 335 & 68 & 99 & 5 & 1 & 173 & 508 \\
\hline 23 & Kab.Semarang & 136 & 164 & 28 & 2 & 330 & 67 & 169 & 4 & 17 & 257 & 587 \\
\hline 24 & Kab.Sragen & 94 & 192 & 94 & 2 & 382 & 111 & 217 & 19 & 23 & 370 & 752 \\
\hline 25 & Kab.Sukoharjo & 243 & 201 & 22 & 2 & 468 & 44 & 181 & 5 & 0 & 230 & 698 \\
\hline 26 & Kab.Tegal & 129 & 163 & 72 & 17 & 381 & 102 & 132 & 48 & 36 & 318 & 699 \\
\hline 27 & Kab.Temanggung & 59 & 58 & 6 & 0 & 123 & 90 & 108 & 4 & 0 & 202 & $\overline{325}$ \\
\hline 28 & Kab.Wonogiri & 141 & 234 & 76 & 11 & 462 & 56 & 129 & 15 & 0 & 200 & 662 \\
\hline 29 & Kab.Wonosobo & 64 & 165 & 26 & 2 & 257 & 55 & 141 & 6 & 0 & 202 & 459 \\
\hline 30 & Kota Magelang & 85 & 109 & 24 & 7 & 225 & 166 & 185 & 12 & 10 & 373 & 598 \\
\hline 31 & Kota Pekalongan & 71 & 65 & 4 & 0 & 140 & 82 & 65 & 4 & 0 & 151 & 291 \\
\hline 32 & Kota Salatiga & 19 & 88 & 31 & 0 & 138 & 33 & 77 & 7 & 0 & 117 & 255 \\
\hline 33 & Kota Semarang & 309 & 393 & 125 & 12 & 839 & 383 & 326 & 23 & 4 & 736 & 1.575 \\
\hline 34 & Kota Surakarta & 268 & 292 & 33 & 1 & 594 & 342 & 408 & 21 & 4 & 775 & 1.369 \\
\hline 35 & Kota Tegal & 101 & 110 & 11 & 2 & 224 & 89 & 129 & 3 & 0 & 221 & 445 \\
\hline & JUMLAH & 4.907 & 5.891 & 1.455 & 166 & 12.419 & 3.498 & 5.207 & 415 & 140 & 9.260 & 21.679 \\
\hline
\end{tabular}

Sumber : Dapodikmen 2014/2015 
Dari sebanyak 21.679 orang Guru dan Tenaga Kependidikan yang berstatus PNS di Jawa Tengah, sebanyak 57,29\% merupakan Guru-Non Guru PNS SMA, sedangkan sebanyak 42,71\% merupakan Guru-Non Guru PNS SMK. Guru dan Non Guru (Tenaga Kependidikan) PNS ini kemungkinan bertugas di sekolah swasta sebagai guru DPK (Diperbantukan).

Dengan berlakunya Undang-Undang Nomor 23 Tahun 2014 tentang Pemerintahan Daerah, pengelolaan pendidikan menengah yang semula menjadi urusan pemerintah daerah kabupaten/kota dialihkan menjadi urusan pemerintah daerah provinsi maka PNS Kabupaten / Kota beralih menjadi PNS Pemerintah Propinsi.

Untuk mengatur hal ini, maka Kepala Badan Kepegawaian Negara menerbitkan Peraturan Kepala BKN no.1 tahun 2016 Tentang Pelaksanaan Pengalihan Pegawai Negeri Sipil Daerah Kabupaten/Kota Yang Menduduki Jabatan Fungsional Guru Dan Tenaga Kependidikan Menjadi Pegawai Negeri Sipil Daerah Provinsi. Pengalihan Pegawai Negeri Sipil sebagaimana ditetapkan terhitung mulai tanggal 1 Oktober 2016.

Sebagai tindak lanjut dari Peraturan Kepala BKN Nomor 1 Tahun 2016 Tersebut Maka Kepala BKN Mengeluarkan Surat Kepala Badan Kepegawaian Negara Nomor : K.2630 Lv.7 I-L /99 Tanggal : 15 Juli 2016. Surat Ini Sengaja Dikeluarkan Sebagai Penjelasan Atas Beberapa Permasalahan Dalam Pengalihan PNS Sebagai Dampak Berlakunya UndangUndang Nomor 23 Tahun 2014. Isi dari Surat Kepala Badan Kepegawaian Negara tersebut diantaranya adalah :

1. PNS yang termasuk wajib dialihkan adalah Guru dan Tenaga kependidikan (Kepala sekolah, pengawas sekolah, pengelola laboratorium/ bengkel, pengelola perpustakaan, pustakawan, dan pejabat pengawas dan pelaksana) pada satuan pendidikan menengah, SMA dan SMK.

2. Pejabat yang Berwenang adalah Sekretaris Daerah Provinsi.

3. Pemberian gaji dan tunjangan Pegawai Negeri Sipil dibebankan pada Anggaran Pendapatan dan Belanja Daerah Provinsi terhitung mulai tanggal 1 Januari 2017. 
Jurnal Ilmu Sosial Vol. 16 | No. 2 | Edisi Juli - Desember 2017 | Hal.72-93

Tabel 6. Perbandingan jumlah Sekolah Menengah dengan Jumlah Guru

\begin{tabular}{|c|c|c|c|c|c|c|}
\hline NO & $\begin{array}{c}\text { KABUPATEN / } \\
\text { KOTA }\end{array}$ & $\begin{array}{c}\text { JUMLAH } \\
\text { KEC }\end{array}$ & $\begin{array}{l}\text { JML SEKOLAH } \\
\text { MENENGAH }\end{array}$ & $\begin{array}{c}\text { JML GURU } \\
\text { SMA }\end{array}$ & $\begin{array}{c}\text { JUMLAH } \\
\text { GURU SMK }\end{array}$ & $\begin{array}{c}\text { TOTAL } \\
\text { GURU }\end{array}$ \\
\hline 1 & Kab Semarang & 19 & 63 & 330 & 257 & $\overline{587}$ \\
\hline 2 & Kab Kendal & 20 & 78 & 300 & 191 & $\overline{491}$ \\
\hline 3 & Kab Demak & 14 & 90 & 290 & 86 & $\overline{376}$ \\
\hline 4 & Kab Grobogan & 19 & 74 & 338 & 137 & 475 \\
\hline 5 & Kab Pekalongan & 19 & 46 & 194 & 142 & 336 \\
\hline 6 & Kab Batang & 15 & 38 & 193 & 109 & 302 \\
\hline 7 & Kab Tegal & 18 & 88 & 381 & 318 & 699 \\
\hline 8 & Kab Brebes & 17 & 99 & 444 & 144 & 588 \\
\hline 9 & Kab Pati & 21 & 64 & 282 & 182 & 464 \\
\hline 10 & Kab Kudus & 9 & 43 & 304 & 205 & $\overline{509}$ \\
\hline 11 & Kab Pemalang & 14 & 67 & 328 & 233 & 561 \\
\hline 12 & Kab Jepara & 16 & 64 & 386 & 174 & 560 \\
\hline 13 & Kab Rembang & 14 & 39 & 335 & 173 & $\overline{508}$ \\
\hline 14 & Kab Blora & 16 & 75 & 240 & 164 & 404 \\
\hline 15 & Kab Banyumas & 27 & 107 & 585 & 484 & 1.069 \\
\hline 16 & Kab Cilacap & 24 & 105 & 502 & 326 & 828 \\
\hline 17 & Kab Purbalingga & 18 & 48 & 223 & 197 & 420 \\
\hline 18 & Kab Banjarnegara & 20 & 34 & 289 & 137 & 426 \\
\hline 19 & Kab Magelang & 21 & 79 & 314 & 176 & $\overline{490}$ \\
\hline 20 & Kab Temanggung & 20 & 37 & 123 & 202 & 325 \\
\hline 21 & Kab Wonosobo & 15 & 42 & 257 & 202 & 459 \\
\hline 22 & Kab Purworejo & 16 & 66 & 424 & 245 & 669 \\
\hline 23 & Kab Kebumen & 26 & 93 & 381 & 386 & 767 \\
\hline 24 & Kab Klaten & 26 & 88 & 623 & 642 & 1.265 \\
\hline 25 & Kab Boyolali & 19 & 78 & 482 & 242 & $\overline{724}$ \\
\hline 26 & Kab Sragen & 20 & 74 & 382 & 370 & 752 \\
\hline 27 & Kab Sukoharjo & 12 & 56 & 468 & 230 & 698 \\
\hline 28 & Kab Karanganyar & 17 & 49 & 399 & 333 & 732 \\
\hline 29 & Kab Wonogiri & 25 & 63 & 462 & 200 & 662 \\
\hline 30 & Kota Semarang & 16 & 182 & 839 & 736 & 1.575 \\
\hline 31 & Kota Salatiga & 4 & 27 & 138 & 117 & 255 \\
\hline 32 & Kota Pekalongan & 4 & 22 & 140 & 151 & 291 \\
\hline 33 & Kota Tegal & 4 & 32 & 224 & 221 & 445 \\
\hline 34 & Kota Magelang & 3 & 31 & 225 & 373 & 598 \\
\hline \multirow[t]{2}{*}{35} & Kota Surakarta & 5 & 85 & 594 & 775 & 1.369 \\
\hline & JUMLAH & 573 & 2.287 & 12.419 & 9.260 & 21.679 \\
\hline
\end{tabular}

Sumber : Data Profil Pendidikan Menengah, Kemdikbud 2013/2014 
Dari tabel 6 di atas bisa kita lihat bahwa jumlah guru di berbagai daerah berbeda beda untuk jumlah dan sebarannya. Hal ini menunjukkan bahwa sebaran guru di Jawa Tengah belum merata. Idealnya daerah yang memiliki jumlah sekolah menengah banyak maka akan memiliki jumlah guru yang banyak. Namun ada daerah yang lebih sedikit memiliki sekolah namun jumlah gurunya lebih banyak. Bisa kita ambil Perbandingan Kabupaten Banyumas dengan Kabupaten Cilacap. Kabupaten Banyumas dengan 107 jumlah sekolah menengah hanya memiliki jumlah guru sebanyak 1.069 orang. Sementara Kabupaten Klaten 88 sekolah menengah memiliki jumlah guru yang lebih banyak dari Kabupaten Banyumas yaitu 1.265 orang. Mutasi pegawai antar Kabupaten/Kota tidak dapat dilakukan dengan mudah karena harus terdapat persetujuan pemda terkait sehingga menyebabkan ketimpangan kompetensi pegawai karena terkesan adanya "pengkaplingan" pegawai provinsi, ataupun pegawai kabupaten/kota.

Ada beberapa jawaban atas tidak meratanya jumlah guru yang notabene merupakan PNS daerah Kabupaten/Kota di Jawa Tengah, salah satunya akibat desentralisasi. Desentralisasi telah membuka peluang lebar bagi setiap daerah untuk berperan lebih besar termasuk dalam pengelolaan PNS dalam hal ini adalah perekrutan dan pengangkatan PNS. Dan yang lebih memprihatinkan seringakali perekrutan tidak menggunakan standar yang jelas dan baku dimana terdapat adanya perbedaan peraturan yang ada dalam UU no 32/2004 tentang pokok-pokok pemerintahan daerah deng UU no. 43/1999 tentang pokok-pokok kepegawaian. Dan implikasinya adalah karena pola rekrutmen yang dilaksanakan selama ini berbeda antar daerah yang satu dengan yang lain, sehingga mendapatkan saringan yang berbeda. Pada akhirnya tingkatan kompetensi aparatur yang dimiliki pemerintah daerah cenderung tidak seimbang. Sebagai contoh dari Hasil Uji Kompetensi Guru (UKG) Kabupaten Sragen untuk tingkat SD dan SMP masih memprihatinkan. Pasalnya dari 10 kabupaten yang menjadi Prioritas di Jawa Tengah, Sragen menempati posisi terakhir.

Jika rekrutmen dan seleksi dilakukan secara efektif, organisasi akan dapat memiliki pegawai sesuai dengan kebutuhan. Dengan demikian efektivitas kegiatan ini dapat diukur dari kesesuaiaan antara jumlah guru dengan jumlah siswa dan jumlah sekolah yang ada di suatu daerah. Kesesuaian jumlah pegawai tentu saja harus pula disertai dengan pemenuhan persyaratan sehingga dapat melakukan pekerjaan sesuai dengan standar.

Dalam era desentalisasi, proses pengelolaan guru menjadi wewenang tersebut daerah dapat mengambil keputusan dengan cepat untuk mengatasi berbagai masalah kepegawaian. Namun demikian, harus tetap diingat bahwa desentralisasi kepegawaian dapat berubah menjadi peluang bagi praktek penyalahgunaan kekuasaan seperti korupsi, kolusi, nepotisme, 


\section{Jurnal Ilmu Sosial Vol. 16 | No. 2 | Edisi Juli - Desember 2017 | Hal.72-93}

politik uang (money politic), lobi-lobi (lobbying), suap (bribery) atau gratifikasi, selain itu, salah satu resiko desentralisasi dan otonomi daerah adalah kemungkinan terjadinya kontrol penuh oleh elit daerah.

Kasus yang terjadi di Kabupaten Sukoharjo sebelum peralihan kewenangan Pendidikan Menengah ke Pemerintah Propinsi Jawa Tengah menunjukkan bahwa politisasi terjadi di era desentralisasi. Di Kabupaten Sukoharjo, mantan Kepala SMAN Tawangsari, Suratno, memprotes mutasi kepala SMA/SMK di Sukoharjo pada September 2016. Mutasi guru itu dinilai melanggar UU No. 23/2014 tentang Pemerintah Daerah dan Surat Edaran (SE) Menteri Dalam Negeri (Mendagri) tentang larangan mutasi guru jenjang SMA dan sederajat. Mutasi kepala sekolah SMA/SMK di Sukoharjo dilaksanakan bersamaan dengan pelantikan Kepala Dinas Pendidikan dan Kebudayaan Sukoharjo pada September 2016. Kala itu, ada beberapa kepala sekolah yang dimutasi antara lain Kepala SMAN 1 Tawangsari, SMAN 1 Bulu, SMAN 1 Mojolaban, serta SMAN 3 Sukoharjo. Mantan Kepala SMAN 1 Tawangsari, Suratno, dimutasi menjadi guru di SMAN 1 Sukoharjo. Padahal, saat itu pengelolaan SMA/SMK masih dalam proses peralihan dari Pemkab Sukoharjo ke Pemprov Jateng.

Proses mutasi dan promosi juga dilaksanakan di Kabupaten Karanganyar. Sebanyak 532 orang itu terdiri dari 225 orang pejabat struktural dan 307 orang pejabat fungsional dilantik. Mutasi dan promosi pejabat fungsional didominasi guru, kepala sekolah, dan dokter. Di sisi lain, 225 orang pejabat struktural itu terdiri atas 79 orang mendapatkan promosi jabatan dan 146 orang mendapatkan mutasi. Mutasi ini juga dilakukan menjelang proses alih kewenangan pendidikan menengah kepada pemerintah Provinsi.

Adanya kebijakan pengangkatan tenaga honorer di daerah menjadi PNS, menimbulkan permasalahan walaupun pengangkatan tenaga honorer terpetakan pada tiap badan kepegawaian daerah (BKD) di tiap daerah tetapi belum menggambarkan kebutuhan kompetensi atas jabatan yang dibutuhkan daerah. Secara umum kecenderungan tenaga honorer ialah pegawai yang ada pada awalnya bergabung berdasarkan sistem kekerabatan, bukan berdasarkan kompetensi yang dipunyainya. Selain itu juga telah pemborosan anggaran keuangan negara dikarenakan seluruh pemerintah daerah Kabupaten/Kota mengalokasikan sebagian besar APBD untuk membayar gaji dan tunjangan Guru di daerah.

Berdasarkan masalah masalah di era desentralisasi tersebut, maka terlihat bahwa pengelolaan Guru yang profesional ke depan membutuhkan perubahan strategi sehingga pemerintah Propinsi mampu menjalankan tugasnya sesuai kebutuhan. Sistem resentralisasi dengan mengembalikan alih kewenangan pendidikan menengah dari pemerintah kabupaten/ Kota ke Pemerintah Propinsi maka akan mampu memfasilitasi untuk mengatur penyediaan 
aparatur yang kompeten, menyusun rencana pengelolaan serta meningkatkan kapasitas pemerintahan yang baik dalam rangka memberi pelayanan publik. Meski kebijakan resentralisasi sudah diberlakukan, banyak kepala daerah yang melakukan mutasi pejabat menjelang alih kewenangan pendidikan menengah kepada pemerintah propinsi.

\section{KESIMPULAN}

Sistem Desentralisasi membuka peluang lebar bagi setiap daerah untuk berperan lebih besar termasuk dalam pengelolaan guru di Kabupaten/Kota. Dominasi Kepala Daerah sangat terlihat dalam proses rekutmen, seleksi, penggajian, pengembangan karier, penempatan, mutasi serta penilian kinerja PNS.

Dengan alih kewenangan pendidikan menengah dari Pemerintah Kabupaten/Kota ke Pemerintah Propinsi maka Guru dan Tenaga kependidikan (Kepala sekolah, pengawas sekolah, pengelola laboratorium/ bengkel, pengelola perpustakaan, pustakawan, dan pejabat pengawas dan pelaksana) pada satuan pendidikan menengah, SMA dan SMK yang semula berstatus PNS Pemerintah Kabupaten/Kota dialihkan menjadi Pegawai Negeri Sipil Daerah Provinsi.

Dengan alih kewenangan tersebut maka Pemerintah Propinsi akan memiliki kewenangan dalam hal mengatur (policy making) dalam seleksi, rekuitmen, pengangkatan, penempatan, mutasi PNS khususnya Guru dan Kepala Sekolah. Dengan sentralisasi kewenangan di tingkat Pemerintah Propinsi maka kesewenangan-wenangan Kepala Daerah Bupati/Kota dalam pengelolaan Guru bisa diminimalisir pada pelaksanaan Pilkada.

Pemberian kewenangan pengelolaan Pendidikan Menengah kepada Pemerintah Propinsi sebaiknya tidak merupakan pemindahan 'kekuasaan' dari Bupati/Walikota kepada Gubernur untuk bisa melakukan politisasi kepada Guru. Untuk itu Pemerintah propinsi sebaiknya menjalankan kewenangan pengelolaan pendidikan menengah tersebut dengan mengedepankan prinsip Good Governance ke depannya.

\section{DAFTAR PUSTAKA}

Akbal, Mohammad , 2016. Harmonisasi Kewenangan Antara Pemerintah Pusat Dan Daerah Dalam Penyelenggaraan Otonomi Daerah”. Jurnal Supremasi Volume XI Nomor 2, Oktober 2016, ISSN 1412-517X diunduh dari file://C:/Users/HP/Downloads/28006670-2-PB.pdf

Ali, Syarif." Konsep Pembaharuan Seleksi Calon Pegawai Negeri Sipil” diunduh dari file:/// $\mathrm{C}$ :/Users/HP/Downloads/konsep-pembaharuan-seleksi-calon-pegawai-negeri-sipil.pdf 
Ardika, Gede Tusan dan Sahrul, 'Konsep Dasar Otonomi Daerah dalam Era Reformasi’, GaleCSwara, Vol. 5 No. 1, Februari 2011

Budi, Kusuma dan Moh. Waspa. Kebijakan Publik Menghadapi Tantangan (Pengalihan Kewenangan Sma Dan Smk Ke Provinsi Kasus Di Kota Metro). Prosiding SNaPP2017 Sosial, Ekonomi, dan Humaniora pISSN 2089-3590 | eISSN 2303-2472 diunduh dari http://proceeding.unisba.ac.id/index.php/sosial/article/view/1243

D, Dewi Sendhikasari. Pengalihan Kewenangan Manajemen Pendidikan Menengah Dari Kabupaten/Kota Ke Provinsi. Majalah Info Singkat Pemerintahan Dalam Negeri : Kajian Singkat terhadap Isu Aktual dan Strategis Vol. VIII, No. 07/I/P3DI/April/2016 diunduh dari http://berkas.dpr.go.id/puslit/files/info_singkat/Info\%20Singkat-VIII-7-IP3DI-April-2016-38.pdf

Dahlan, Muhammad Arif. "Kebijakan Pendidikan Gratis Di Tingkat Regional : Konsep dan Pelaksanaan di Kabupaten Rembang” diunduh dari file://C:/Users/HP/Downloads/ KEBIJAKAN_PENDIDIKAN_GRATIS_DI_TINGKAT_R.pdf

Damayanti, Sella Nova . 2017. “Analisis Prospektif Kebijakan Pengalihan Kewenangan Pendidikan Menengah dari Pemerintah Kota Surabaya ke Pemerintah Provinsi Jawa Timur Berdasarkan UU No. 23 Tahun 2014 Tentang Pemerintahan Daerah. Jurnal Kebijakan dan Manajemen Publik Volume 5, Nomor 3 September - Desember 2017 ISSN 2303-341X diunduh dari http://www.journal.unair.ac.id/download-fullpaperskmp1beaefc49ffull.pdf

E, Koswara. 2004. Otonomi Daerah untuk Demokrasi dan Kemandirian Rakyat, Yayasan Pariba, Jakarta, 2004

Harris, Samsudin. 2005. Desentralisasi dan Otonomi Daerah. Jakarta : LIPI Press Hasbullah. 2006. Otonomi Pendidikan. Jakarta : PT RajaGrafindo Persada.

Moleong, Lexy . 1999. Metode Penelitian Kualitatif, Jakarta : Rajawali, Jakarta

Nasution, Marihot. Pengalihan Kewenangan Pendidikan Menengah ke Pemerintah Provinsi, Buletin APBN, Pusat Kajian Anggaran Badan Keahlian DPR RI, Edisi 16. Vol. I. Agustus 2016 diunduh dari http://berkas.dpr.go.id/puskajianggaran/buletin-apbn/public -file/buletin-apbn-public-16.pdf

Panjaitan, Dennis Abel Timotius,dkk. Analisis Yuridis Terhadap Peralihan Bidang Pendidikan Menengah Dari Pemerintah Kabupaten/Kota Kepada Pemerintah Provinsi Sebagai Implementasi Undang-Undang Nomor 23 Tahun 2014 Tentang Pemerintahan Daerah. Diponegoro Law Journal Volume 6, Nomor 2, Tahun 2017 diunduh dari https://ejournal3.undip.ac.id/index.php/dlr/article/view/17340 
Rodiyah, Isnaini . "Pengelolaan Kepegawaian Daerah Di Era Desentralisasi”. Kalamsiasi : Vol. 5 No. 1 ISSN 1412-7695 (2012) diunduh dari http://eprints.umsida.ac.id/38/1/ PENGELOLAAN\%20KEPEGAWAIAN\%20DAERAH.pdf

Rohman, Arif dan Teguh Wiyono. 2010. Education Policy in Decentralization Era. Yogyakarta : Pustaka Pelajar

Romli, Lili . 2007. Potret Otonomi Daerah dan Wakil Rakyat di Tingkat Lokal, Yogyakarta : Pustaka Pelajar

Septhinna, Ega dkk. "Proses Rekrutmen Sumber Daya Aparatur Dinas Pendidikan (Studi Kasus Badan Kepegawaian Daerah Kota Malang)" diunduh dari https:// media.neliti.com/media/publications/73958-ID-proses-rekrutmen-sumber-dayaaparatur-di.pdf

Sugiyono. 2009. Metode Penelitian Kuantitatif dan Kualitatif dan $R \& D$. Bandung : Alfabeta

Suyahman. 2016. "Analisis Kebijakan Pendidikan Gratis Di Sekolah Menengah Atas Dalam Kaitannya Dengan Kualitas Pendidikan Menengah Atas”. Jurnal Pendidikan Kewarganegaraan: Volume 6, Nomor 2, Nopember 2016 diunduh dari https:// media.neliti.com/media/publications/120772-ID-analisis-kebijakan-pendidikan-gratisdi.pdf

Syarif, Hidayat . 2000. Refleksi Otonomi Daerah dan Tantangan ke Depan, Jakarta : Pustaka Quantum

Syarif, Hidayat dan Benyamin Hoessein. 2000 , "Desentralisasi dan Otonomi Daerah : Perspektif Teoritis dan Perbandingan" dalam Samsuddin Haris (ed), Paradigma Baru Otonomi Daerah. Jakarta.

Undang-Undang Nomor 20 Tahun 2003 tentang Sistem Pendidikan Nasional (Lembaran Negara Republik Indonesia Tahun 2003 Nomor 78, Tambahan Lembaran Negara Republik Indonesia Nomor 4301);

Undang-Undang Nomor 14 Tahun 2005 tentang Guru dan Dosen (Lembaran Negara Republik Indonesia Tahun 2005 Nomor I57, Tambahan Lembaran Negara Republik Indonesia Nomor 4586);

Undang-Undang Nomor 5 Tahun $2 \mathrm{O} 4$ tentang Aparatur Sipil Negara (Lembaran Negara Republik Indonesia Tahun $2 \mathrm{O} 4$ Nomor 6, Tambahan Lembaran Negara Republik Indonesia Nomor 5a9al;

Undang-Undang Nomor 23 Tahun 2014 tentang Pemerintahan Daerah (Lembaran Negara Republik Indonesia Tahun 2014 Nomor 244, Tambahan Lembaran Negara Republik Indonesia Nomor 5587 
Peraturan Kepala Badan Kepegawaian Negara Nomor 1 Tahun 2016 Tentang Pelaksanaan Pengalihan Pegawai Negeri Sipil Daerah Kabupaten/Kota Yang Menduduki Jabatan Fungsional Guru Dan Tenaga Kependidikan Menjadi Pegawai Negeri Sipil Daerah Provinsi diunduh dari http://www.bkn.go.id/wp-content/uploads/2016/02/PERKABKN-NOMOR-1-TAHUN-2016-PELAKSANAAN-PENGALIHAN-PNS-DAERAHKABUPATEN-KOTA-YANG-MENDUDUKI-JF-GURU-DAN-TENAGAKEPENDIDIKAN-MENJADI-PNS-DAERAH-PROVINSI.pdf

Surat Kepala Badan Kepegawaian Negara Nomor : K.26-30 /V.7I-L/99 Tanggal : 15 Juli 2016. Penjelasan Atas Beberapa Permasalahan Dalam Pengalihan PNS Sebagai Dampak Bertakunya Undang-Undang Nomor 23 Tahun 2014diunduh dari http:// www.bkn.go.id/wp-content/uploads/2016/07/SURAT-KEPALA-BKN-NOMOR-K.2630-V.71-1-99-PENJELASAN-ATAS-BEBERAPA-PERMASALAHAN-SEBAGAIDAMPAK-BERLAKUNYA-UU-NOMOR-23-TAHUN-2014.pdf 